\title{
Late Miocene deep-sea trace fossil associations in the Vera Basin, Almería, Southeastern Spain
}

\author{
Allan A. EKDALE I* $^{*}$ Jordi M. de GIBERT \\ ${ }^{1}$ Department of Geology and Geophysics, University of Utah, FASB 383, 115 South 1460 East, Salt Lake City, UT $84112-$ \\ 0102, U.S.A.; a.ekdale@utah.edu \\ ${ }^{2}$ Deceased (September 23, 2012) \\ * Corresponding author
}

Ekdale, A. \& Gibert, J.M. 2014. Late Miocene deep-sea trace fossil associations in the Vera Basin, Almería, Southeastern Spain. [Asociaciones de trazas fósiles marinas profundas del Mioceno superior de la cuenca de Vera, Almería, Sureste de España]. Spanish Journal of Palaeontology, 29 (1), 95-104.

\begin{abstract}
The Vera Basin in southeastern Spain was a small, tectonically active depocenter throughout the Miocene. In the early Messinian, approximately 7.2 to 6.0 million years ago, the basin received hemipelagic marl deposits that were punctuated by turbidite events. Soles of thin, turbidite sand beds preserve an abundance of pre-depositional graphoglyptid (agrichnial) burrows that represent diverse deep-sea ichnocoenoses, including Paleodictyon, Urohelminthoida and Helminthorhaphe. Post-depositional feeding burrows, including Ophiomorpha (created by crustaceans) and Scolicia (created by echinoids) occur sparsely in some turbidite beds, but they are far out-numbered by the predepositional agrichnial burrows. This diverse trace fossil association occurred in a small, short-lived, coastal basin that apparently never got more than a few hundred meters deep. As the basin opened up and flooded in the Late Miocene, the sea floor was colonized rapidly by benthic organisms of uncertain biological affinity, who created a wide variety of
\end{abstract}

RESUMEN

La Cuenca de Vera, en el sureste español, fue un pequeño depocentro tectónicamente activo durante todo el Mioceno. A principios del Messiniense, hace aproximadamente 7,26,0 millones de años, la cuenca recibió depósitos margosos hemipelágicos, interrumpidos por episodios turbidíticos. En la base de los niveles de arenas turbidíticas se conserva una gran cantidad de grafoglíptidos pre-deposicionales (agrichnia) que representan diversas icnocenosis de aguas profundas, incluyendo Paleodictyon, Urohelminthoida y Helminthorhaphe. En algunas turbiditas aparecen esporádicamente algunas trazas de alimentación postdeposicionales, incluyendo Ophiomorpha (producida por crustáceos) y Scolicia (producida por equínidos), pero en mucho menor número que los grafoglíptidos predeposicionales. Esta diversa asociación de trazas fósiles se produjo en una pequeña cuenca litoral de corta duración que, al parecer, nunca superó unos pocos cientos de metros de profundidad. A medida que la cuenca se abría y se inundaba 
anastomosing and meandering tunnels, in which a nourishing food supply (probably bacteria or fungi) apparently grew on mucus-lined walls.

Keywords: Agrichnia, fractal, graphoglyptid, ichnology, turbidite. en el Mioceno superior, el fondo marino era rápidamente colonizado por organismos bentónicos, de afinidades biológicas inciertas, que produjeron una amplia variedad de túneles anastomosados y meandriformes, en cuyas paredes recubiertas de mucosidad aparentemente se originó un suministro de alimentos nutritivos (probablemente bacterias u hongos).

Palabras clave: Agrichnia, fractal, grafoglíptido, icnología, turbidita.

\section{INTRODUCTION}

Deep-sea trace fossils are among the most intriguing of all ichnotaxa to ichnologists, because they typically are so highly patterned, morphologically diverse and geometrically regular. Yet their producers in the modern ocean remain elusive, and their ethologic significance is subject to conjecture and debate. Trace fossils occurring in deep-marine environments fit within the Nereites Ichnofacies of Seilacher $(1964,1967)$, and they commonly are preserved in convex hyporelief on turbidite beds, where they are known as graphoglyptid burrows (Seilacher, 1977; Uchman, 2003).

The Vera Basin in the province of Almería, southeastern Spain, was tectonically active throughout Miocene (and later) time. For a short time in the early Messinian (around 7.2 to 6.0 million years ago), the basin received hemipelagic marl deposits that were punctuated by turbidite events. Soles of multiple, thin, turbidite sand beds in the Vera Basin preserve an abundance of predepositional horizontal burrows, most of which are geometrically ornate agrichnia that are widely recognized as hallmarks of deep-sea ichnocoenoses (Paleodictyon, Urohelminthoida, Helminthorhaphe). Post-depositional burrows, such as Ophiomorpha (produced by crustaceans) and Scolicia (produced by echinoids), occur sparsely in some of the Vera Basin turbidites, but they are far outnumbered by the pre-depositional agrichnia.

What makes this agrichnial trace fossil association of particular interest to palaeontologists and sedimentologists is that it occurred in a small, short-lived, coastal basin that apparently never got more than a few hundred meters deep. As the basin opened up and flooded in the Late Miocene, the sea floor was colonized rapidly by tiny benthic farmers of uncertain biological affinity, who created networks of anastomosing or meandering tunnels, in which a nourishing food supply (probably bacteria or fungi) apparently grew on mucus-lined walls.

\section{GEOLOGIC SETTING}

The Vera Basin was a narrow, tectonically controlled, marine trough in the province of Almería during the Late Miocene (Braga et al., 2001, 2006). It was a small, shortlived basin (Fig. 1), and the maximum water depth probably was much less than $1000 \mathrm{~m}$. Most of the exposures in Almería are inland roadcuts. Turbidite sandstone beds are thin and locally discontinuous, suggesting small-scale slope deposits without the development of extensive submarine fan systems.

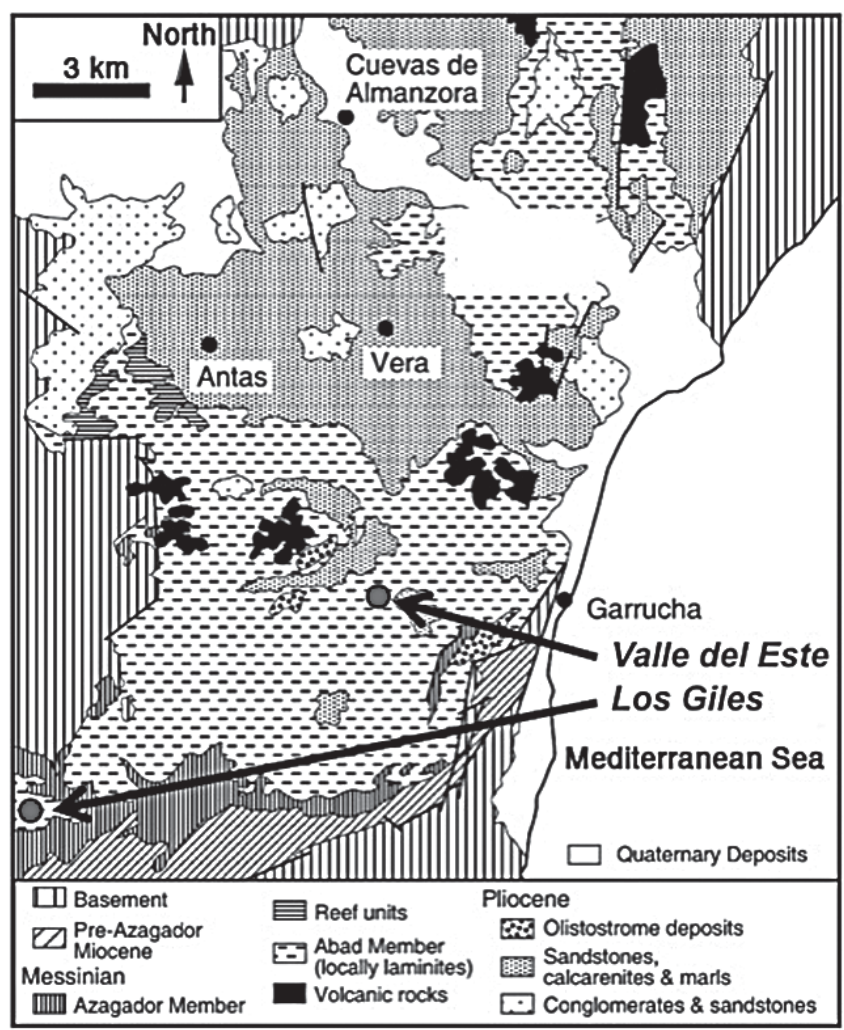

Figure 1. Geologic map of the Vera Basin, Almería, southeastern Spain (modified after Braga et al., 2006, fig. 13). Two principal trace fossil sampling sites (Valle del Este and Los Giles) are indicated by arrows. 
The sandstone turbidites contain diverse suites of predepositional and post-depositional trace fossils, indicating episodic deposition resulting from active vertical tectonism in the basin (Montenat \& Seilacher, 1978; Wood \& Poiré, 1998). The pre-depositional trace fossils are graphoglyptid burrows preserved on the soles of beds representing Bouma $a, b$ and $c$ intervals, and the post-depositional trace fossils occur in full relief within some of the same turbidite sand beds. The intervening fine-grained intervals contain no discernible burrows, but lack of primary laminae in those intervals suggests pervasive bioturbation.

\section{TRACE FOSSILS}

\subsection{Ichnotaxa}

Trace fossils in the late Miocene deep-water facies of the Vera Basin include both pre-depositional and postdepositional suites. Pre-depositional trace fossils are those that were created during the long intervals between turbidite events, and post-depositional trace fossils are those that colonized turbidite sands shortly after they were deposited as event beds (Seilacher, 1962; Kern, 1980). Ichnotaxonomic assignments of the Vera Basin trace fossils mentioned in this paper follow those described by Książkiewicz (1970, 1977), Seilacher (1977) and Uchman (2008).

Pre-depositional trace fossils were agrichnial graphoglyptid burrows (Figs 2 to 5). The most common pre-depositional ichnotaxa found in the Vera Basin are Paleodictyon strozzii, Helminthorhaphe flexuosus, and Urohelminthoida dertonensis. Less common predepositional ichnotaxa in these deposits include Paleodictyon imperfectum, Paleodictyon minimum, Helminthorhaphe japonica, Urohelminthoida appendiculata, Helicorhaphe tortilis, Helicolithus tortuosus, Desmograpton ichthyforme, Desmograpton isp., Glockeria glockeri, and Lorenzinia appenninica. The pre-depositional graphoglyptid burrows are preserved in convex hyporelief on soles of thin, turbidite sand beds (Bouma $a, b$ and $c$ intervals), which represent catastrophic depositional events that scoured and then filled the pre-existing open tunnels of the grapohoglyptids.

Post-depositional trace fossils were deposit-feeding grazing (pascichnial) and sediment-mining (fodinichnial) burrows (Figs 2 and 5). The most common post-depositional ichnotaxa found in the Vera Basin are Ophiomorpha cf. $O$. rudis, Thalassinoides suevicus, and Scolicia prisca. Less common post-depositional ichnotaxa include Chondrites isp., Gordia marina, Helminthopsis tenuis, Granularia isp., and Protovirgularia isp.

\subsection{Palaeoethologic interpretation}

Several important lines of evidence indicate that the graphoglyptid trace fossils represent farming (agrichnial) behavior within the sedimentary substrate. In support of the farming hypothesis for graphoglyptid burrows, preservational aspects clearly demonstrate that they are pre-depositional, meaning that they were formed during the long intervals of time between the short-lived turbidite events. As such, they represent the equilibrium community of K-selected specialist taxa inhabiting a quiet sea floor (see Ekdale, 1985). The graphoglyptids typically occur in geometrically and ichnotaxonomically diverse trace fossil associations, rather than in low-diversity (or even monotypic) associations, as is commonly observed for opportunistic $r$-selected ichnotaxa, such as Ophiomorpha or Zoophycos, or for grazing trails of mobile animals, such as Heminthoida or Scolicia. In the limited occurrence of turbidites in the Vera Basin, at least 13 ichnospecies of agrichnia have been recognized, which is a notably high ichnotaxonomic diversity.

Among graphoglyptids, the occurrence of many different geometric configurations on the same basic theme (i.e., shallow infaunal, horizontal, unlined, farming burrows) may reflect fine-scale niche partitioning within the deep-sea benthic community during the long, stable intervals between turbidite events. Such a level of fine subdivision of niches that represent the same general behavioral category is consistent with the complexity of community structure of diverse K-selected equilibrium taxa (Valentine, 1969), and it should be expected that this aspect will be reflected in the spectrum of trace fossil patterns created by K-selected burrowers (Ekdale, 1985).

The graphoglyptid traces were maintained as open burrows during occupation. They exhibit sharp, clear burrow margins and uniform tunnel diameters. The tunnels never contain feces, pellets or meniscate backfill, thus making it possible for the animals to move and forth throughout the tunnel system. In some well-preserved specimens, such as Paleodictyon, there were multiple, short, vertical shafts positioned at regular intervals throughout the burrow system (see also Rona et al., 2009; Seilacher, 1977). These shafts presumably allowed for ventilation of the entire system of tunnels.

\subsection{Fractal analysis}

The most striking characteristic of graphoglyptid trace fossils is the regular geometric pattern of the tunnel system, which includes a wide variety of networks, spirals and meanders. The regular configuration of the graphoglyptid tunnel system lends itself readily to fractal geometric analysis. A fractal is a geometric entity that can be thought of as a shape that exhibits the three fundamental 

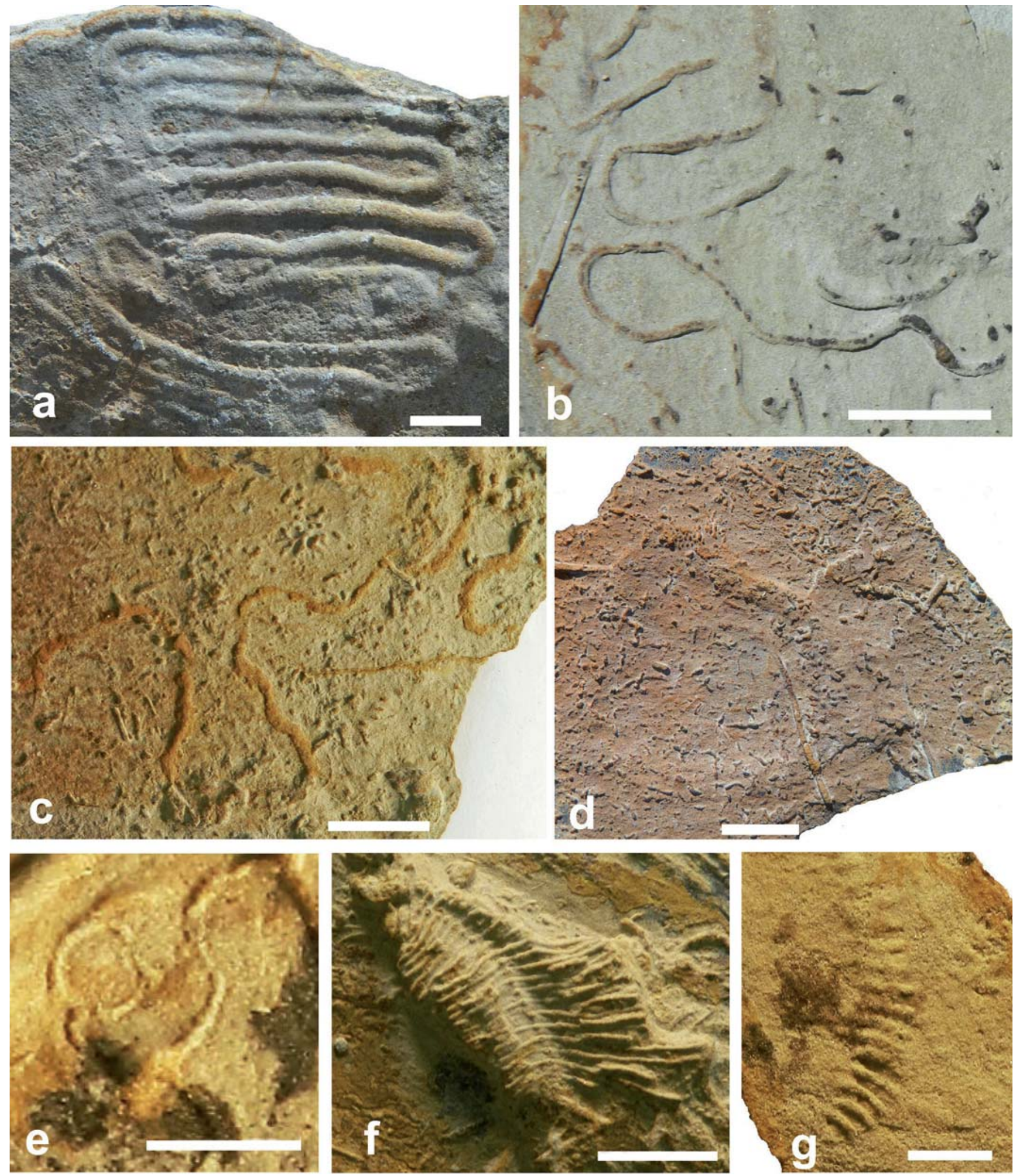

Figure 2. Pre-depositional graphoglyptid (agrichnial) and post-depositonal (pascichnial) trace fossils from the Vera Basin. a) Helminthorhaphe flexuosus, scale $=1 \mathrm{~cm}$. b) $H$. japonica, scale $=2 \mathrm{~cm}$. c) Helminthopsis tenuis, scale $=2 \mathrm{~cm}$. d) Glockeria glockeri $(G l)$ and Lorenzinia appenninica $(L o)$, scale $=2 \mathrm{~cm}$. e) Gordia marina, scale $=0.5 \mathrm{~cm}$. f) Desmograpton ichthyforme, scale $=2 \mathrm{~cm}$. g) Helicolithus tortuosus, scale $=1 \mathrm{~cm}$. 

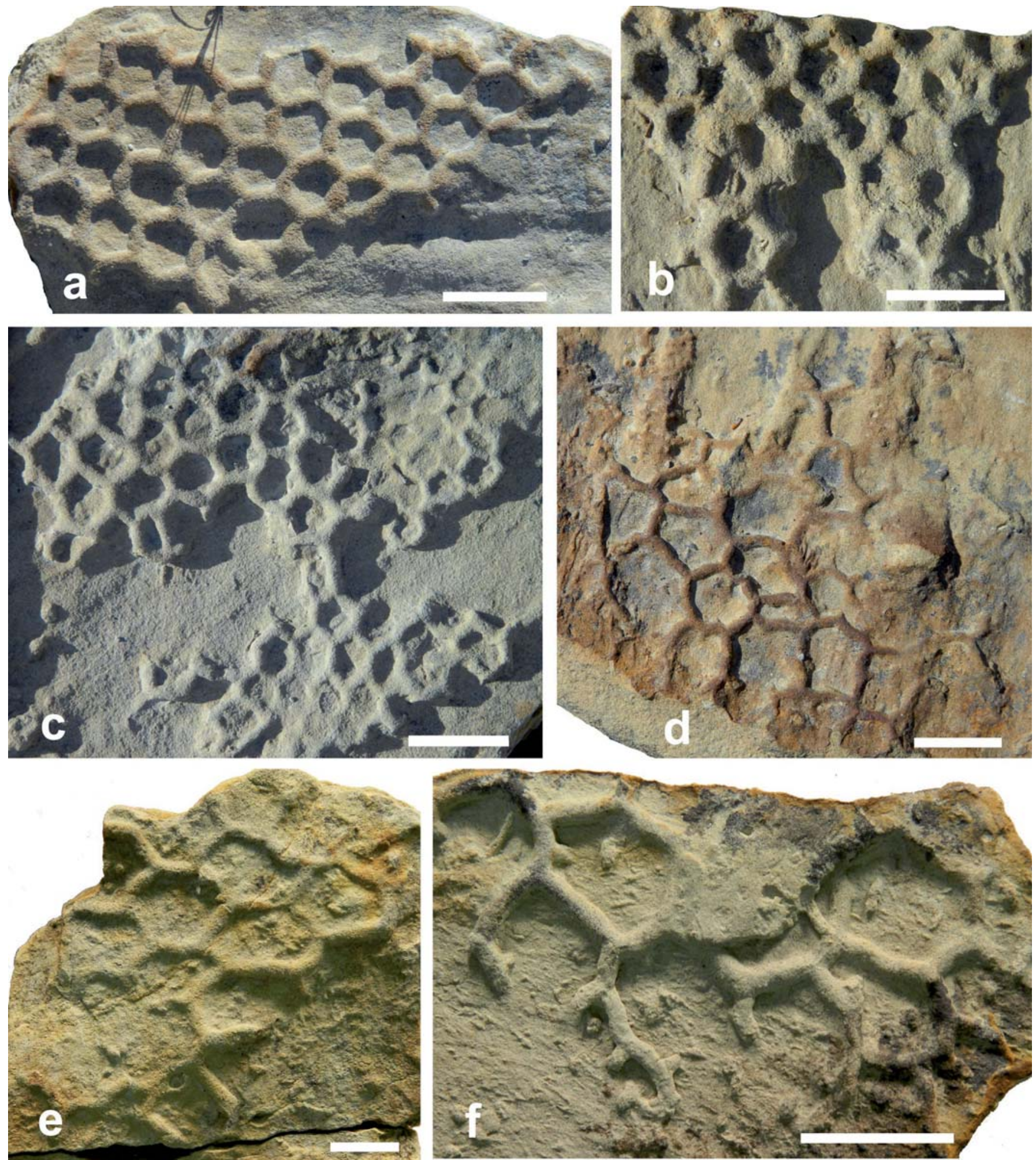

Figure 3. Pre-depositional graphoglyptid (agrichnial) trace fossils from the Vera Basin. a) Paleodictyon stozzii, scale 2 cm. b) $P$. minimum, scale $2 \mathrm{~cm}$. c) $P$. stozzii, scale $2 \mathrm{~cm}$. d) $P$. imperfectum, scale $2 \mathrm{~cm}$. e) $P$. imperfectum, scale $1 \mathrm{~cm}$. f) $P$. imperfectum, scale $2 \mathrm{~cm}$.

properties of scale invariance, self-similarity and fractional dimensionality (Mandelbrot, 1983; Feder, 1988):

a) A fractal is scale invariant; it possesses the same geometric attributes regardless of its size. It is axiomatic in ichnotaxonomy that most (or all?) trace fossils should be scale invariant - that is, we do not consider size alone to be a valid ichnotaxobase. Thus, Skolithos is Skolithos, regardless of how large or how small it is. 
b) A fractal occupies a fractal (fractional) dimension that is, the fractal dimension is a real number rather than an integer. In other words, a fractal is a shape that will occupy a dimension between 1 and 2, or between 2 and 3 .

c) A fractal exhibits the property of self-similarity that is, all component parts of the shape possess the same geometric attributes as every other part as well as the same geometric attributes of the entire shape.

Fractals occur all around us in nature. For example, the branching geometry of channels in the drainage basin of a large river system typical approximates the fractal properties of self-similarity as well as scale invariance and fractal dimension. The same can be said of the branching geometry of the limbs of a large tree, or the details of the jagged outline of a rocky coastline (Jiang \& Plotnick, 1998), or even the vertical distribution of stratigraphic discontinuities in a sedimentary sequence (Plotnick, 1986).

A few ichnologists have looked at trace fossils from the perspective of fractal geometry (Gibert et al., 1999; Honeycutt \& Plotnick, 2005; Baucon, 2010; Lehane \& Ekdale, 2012). Many graphoglyptid trace fossils, such as Paleodictyon, exhibit the essential fractal attributes of scale invariance, fractal dimension and self-similarity.

Scale invariance is widely observed in many common trace fossils, such as Skolithos and Thalassinoides. In the Vera Basin, Paleodictyon sometimes occurs in multiple sizes within the very same bed (Fig. 4a). There is some indication that the mesh size and tunnel diameter of Paleodictyon increase with depth in the sediment, but the basic geometric attributes remain the same. Multiple sizes of Paleodictyon in direct association with one another also have been observed in modern deep-sea cores (Ekdale, 1980, fig. 1d).

The fractal dimension of trace fossils can be calculated without great difficulty. While scale invariance is fairly straightforward to observe, calculation of the fractal dimension of a trace fossil may be a little less straightforward to determine. For example, the fractal dimension can be calculated graphically using the standard box counting method (Lehane \& Ekdale, 2012). The trace fossil shape is emplaced on a grid consisting of square boxes of consistent size, and the total number of boxes containing portions of the shape is counted. The box size then is reduced by a set amount, and the boxes are counted again. The box size is reduced further, and the boxes are counted yet again. This process of counting the trace fossil shape occupying boxes of ever-decreasing sizes is repeated multiple times, and a log plot of the numbers of the counts from all iterations forms a straight line. The slope of that line provides the fractal dimension.

Lehane \& Ekdale (2012) analyzed the fractal characteristics of well-preserved agrichnial, pascichnial and fodinichnial trace fossils in the Eocene flysch sequence exposed in sea cliffs near Zumaia, northwestern Spain.
They used the standard box counting method to calculate fractal dimensions of trace fossils at Zumaia, and they determined that fractal dimensions of deposit-feeding trace fossils were relatively high. For pascichnial and fodinichnial (deposit-feeding) traces, the fractal dimension (D) ranges from 1.75 to 1.85 . They also determined that fractal dimensions of agrichnial trace fossils were significantly lower. For agrichnial (farming) traces, the fractal dimension (D) ranges from 1.27 to 1.63. Thus, although deposit-feeding and farming traces both occupy a dimension somewhere between 1 and 2, the higher fractal dimension of the deposit-feeding traces indicates a more thorough filling of the object space (Lehane \& Ekdale, 2012).

Baucon (2010) likewise calculated the fractal dimensions of selected deep-water trace fossils from Italy and elsewhere. He found that the fractal dimensions of fodinichnial and pascichnial deposit-feeding burrows, such as Zoophycos $\left(\mathrm{D}_{\text {Zoophycos }}=1.78\right)$ and Helminthoida labyrinthica $\left(\mathrm{D}_{\text {Helminthoida }}\right.$ labyrinthica $=1.75)$, are consistently higher than those of most of the agrichnial burrows that he examined, such as Paleodictyon strozzii $\left(\mathrm{D}_{\text {Paleodictyon strozzii }}=1.61\right)$ and Paleodictyon imperfectum $\left(\mathrm{D}_{\text {Paleodiction imperfectum }}=1.56\right)$.

For this study, the fractal dimensions of a few agrichnial trace fossils from Vera Basin were calculated (Fig. 6; Table 1). Results for the Paleodictyon and Urohelminthoida specimens show that $\mathrm{D}_{\text {Paleodictyon }}=1.596$ to $1.711(\mathrm{n}=9)$, and $\mathrm{D}_{\text {Urohelminthoida }}=1.610$ to $1.752(\mathrm{n}=$ 4). As indicated above, these numbers are quite consistent with those found for agrichnial trace fossils elsewhere (Baucon, 2010; Lehane \& Ekdale, 2012), and they are less than might be expected for pascichnial or fodinichnial trace fossils.

In contrast to agrichnial farming burrows, fodinichnial deposit-feeding burrows, such as Zoophycos or Phycodes, are constructed to maximize extraction of food in organicrich sediment, much like a strip mining operation. Fodinichnia often optimize coverage of the sediment by closely packing or even overlapping the tunnels within the burrow system. This is the reason why one might expect their fractal dimensions to be higher than those of agrichnia. Pascichnial deposit-feeding burrows, such as Scolicia or Helminthoida, are produced by organisms grazing on a surface or along a horizontal plane within the sediment in order to ingest food-rich sediment while on the move. Pascichnia often are produced by groups (herds) of individuals, whose densely spaced trails commonly overlap and cross-cut one another. Thus, like fodinichnia, pascichnia too might be expected to exhibit higher fractal dimensions than agrichnia.

Agrichnial farming burrow systems, such as Paleodictyon, typically are laid out in a regular geometric pattern with uniform distances maintained between adjacent tunnels, much like the evenly spaced rows of a farmer's field. Agrichnia generally are composed of 

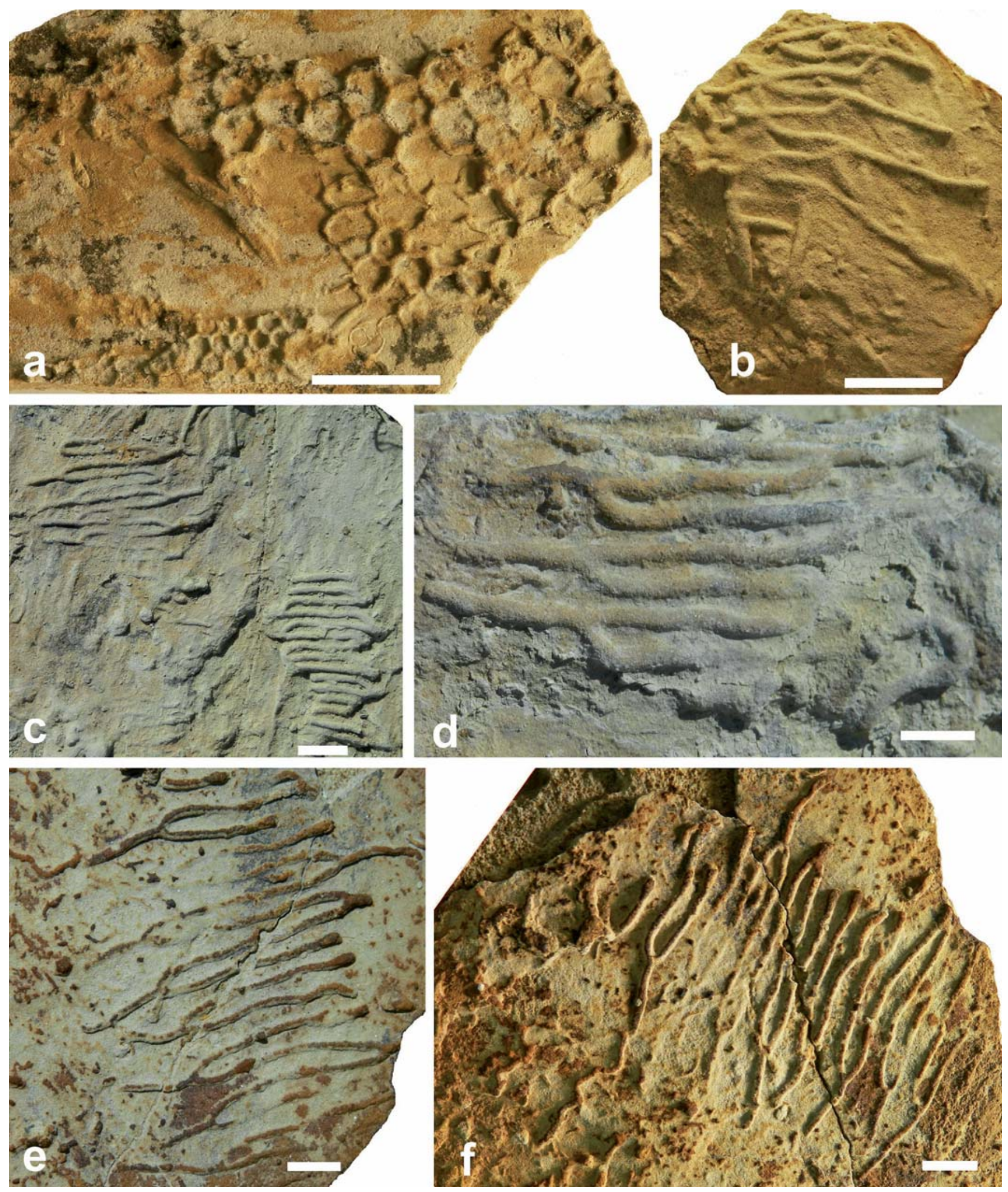

Figure 4. Pre-depositional graphoglyptid (agrichnial) trace fossils from the Vera Basin. a) Paleodictyon strozzii, showing large (upper), medium (middle) and small (lower) mesh sizes, scale $=2 \mathrm{~cm}$. The large and medium meshes appear to be connected within the same burrow system. It is possible that the medium and small meshes also may be connected in the same burrow system, but preservational detail of the trace fossil is insufficient to discern a direct connection of those meshes with certainty. b-c) Urohelminthoida dertonensis, scale $=2 \mathrm{~cm}$. d-f) $U$. dertonensis, scale $=1 \mathrm{~cm}$. 

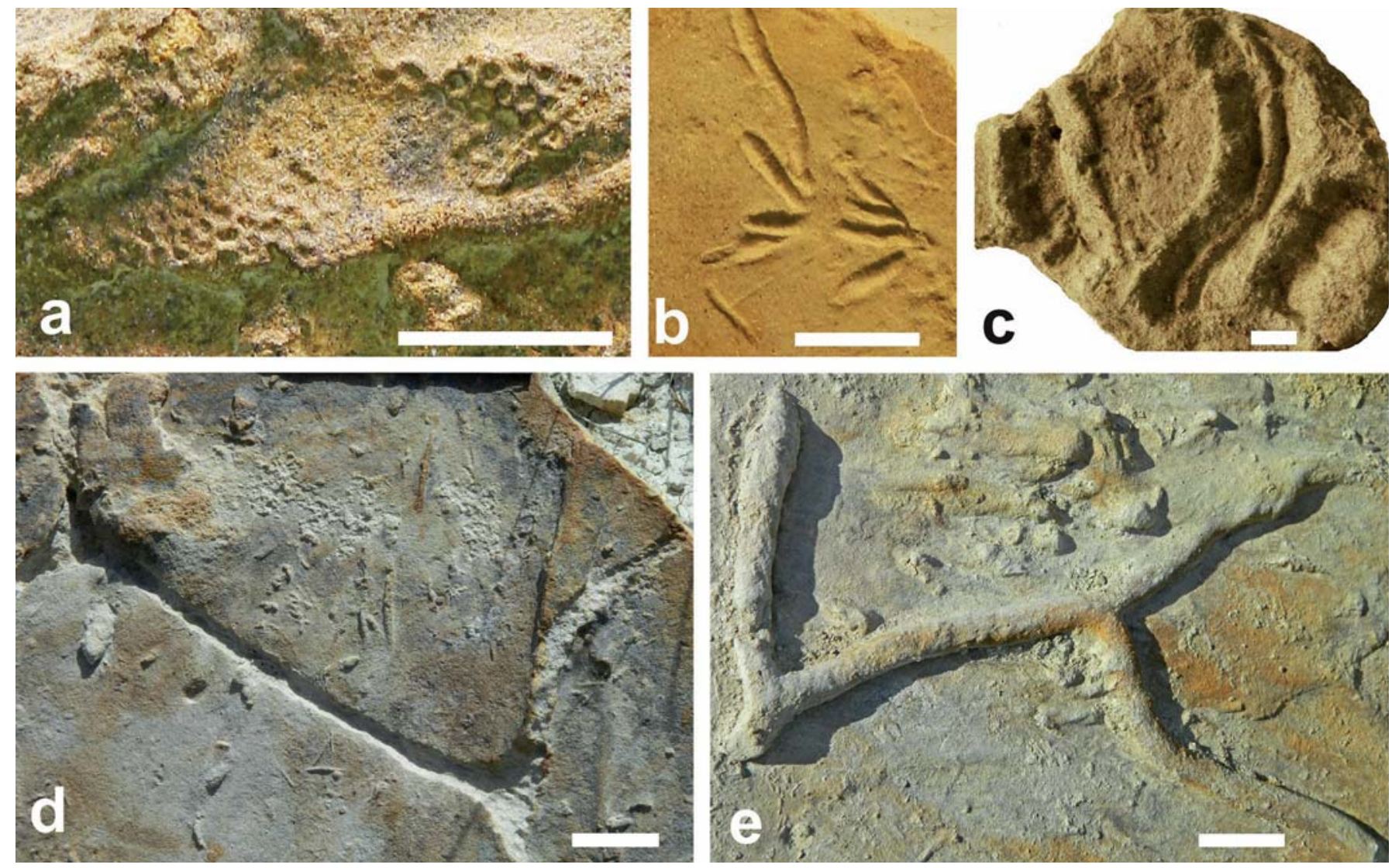

Figure 5. Pre-depositional graphoglyptid (agrichnial) and post-depositonal (fodinichnial and pascichnial) trace fossils from the Vera Basin. a) Paleodictyon minimum, scale $=1 \mathrm{~cm}$. b) Chondrites isp., scale $=1 \mathrm{~cm}$. c) Scolicia prisca, scale $=1 \mathrm{~cm}$. d) Ophiomorpha $\mathrm{cf}$. O. rudis, scale $3 \mathrm{~cm}$. e) Thalassinoides suevicus, scale $=3 \mathrm{~cm}$.

multiple tunnels that may be interconnected in a regular fashion, but they never overlap indiscriminately.

The observed differences in fractal dimensions suggests that feeding patterns represented by graphoglyptid burrows are less constructed for maximum coverage of the sediment than are the feeding patterns of deposit feeders or grazers. Thus, in the Eocene flysch of Zumaia in northwestern Spain, Lehane \& Ekdale (2012) found that the average fractal dimension for Zoophycos, which is $\mathrm{D}_{\text {Zoophycos }}=1.90$, is significantly higher than the average fractal dimension for Paleodictyon, which is $\mathrm{D}_{\text {Paleodictyon }}=1.30$.

\section{DISCUSSION}

While post-depositional fodinichnia of crustaceans (Ophiomorpha) and pascichnia of echinoids (Scolicia) occur sparsely in some of the Vera Basin turbidites, they are far out-numbered by the pre-depositional agrichnia that dominate the trace fossil associations. What makes the agrichnial trace fossil association in the Vera Basin of particular interest is that it occurred in a small, short-lived, coastal basin that apparently never got more than a few hundred meters deep. As the basin opened up and flooded in the Late Miocene, the sea floor was colonized rapidly by tiny benthic farmers of uncertain biological affinity, who created networks of anastomosing or meandering tunnels, in which a nourishing food supply (probably bacteria or fungi) grew on mucus-lined walls. It seems clear that the ecologic conditions at the sea floor rather than the absolute water depth influenced the occurrence of the agrichnial trace fossils in this basin.

The agrichnial assemblage in the Vera Basin is one of only a few examples of very young (6 to 7 million years old) graphoglyptid trace fossils, and thus it serves to link the well-known Cretaceous-Palaeogene record of such fascinating trace fossils (Seilacher, 1974, 1977, 2007; Wetzel, 1983, 2000; Uchman, 2003) with their elusive modern representatives observed in deep-sea bottom photos (Rona et al., 2009) and recovered in deep-sea cores (Ekdale, 1980). 
Fractal Dimension of Spanish Trace Fossils

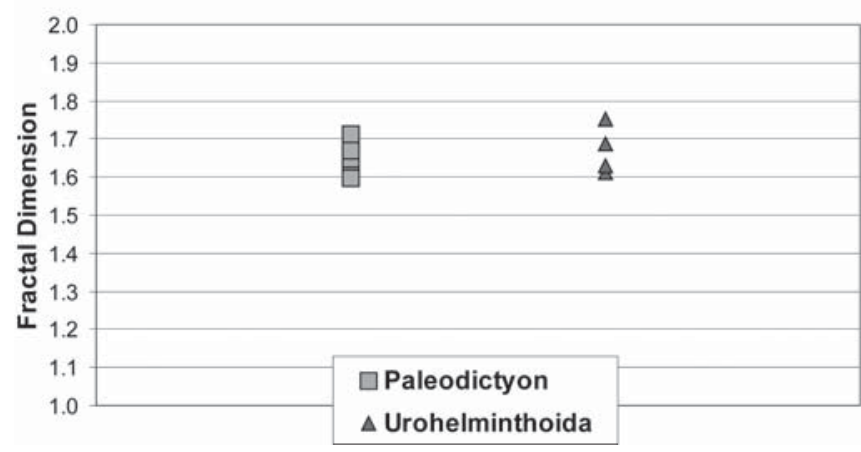

Figure 6. Results of fractal analyses of several specimens of selected graphoglyptid trace fossils from the Vera Basin (graph courtesy of J. R. Lehane, 2012). Fractal dimension of Paleodictyon $\left(\mathrm{D}_{\text {Paleodictyon }}\right)$ ranges from 1.596 to $1.711(\mathrm{n}=9)$, and fractal dimension of Urohelminthoida $\left(\mathrm{D}_{\text {Urohelminthoida }}\right)$ ranges from 1.610 to $1.752(\mathrm{n}=4)$.

Table 1. Fractal dimension and standard error of nine Paleodictyon and four Urohelminthoida specimens from the Vera Basin, as shown in Figure 6.

\begin{tabular}{lll}
\hline Ichnogenus & $\begin{array}{l}\text { Fractal } \\
\text { Dimension }\end{array}$ & $\begin{array}{l}\text { Standard } \\
\text { Error }\end{array}$ \\
\hline Paleodictyon & 1.658 & \pm 0.006 \\
Paleodictyon & 1.668 & \pm 0.005 \\
Paleodictyon & 1.677 & \pm 0.012 \\
Paleodictyon & 1.608 & \pm 0.006 \\
Paleodictyon & 1.648 & \pm 0.013 \\
Paleodictyon & 1.689 & \pm 0.016 \\
Paleodictyon & 1.711 & \pm 0.007 \\
Paleodictyon & 1.670 & \pm 0.012 \\
Paleodictyon & 1.596 & \pm 0.009 \\
Urohelminthoida & 1.610 & \pm 0.006 \\
Urohelminthoida & 1.687 & \pm 0.008 \\
Urohelminthoida & 1.752 & \pm 0.005 \\
Urohelminthoida & 1.630 & \pm 0.006 \\
\hline
\end{tabular}

\section{ACKNOWLEDGMENTS}

This research was supported by University of Barcelona, University of Utah, Spanish Ministry of Research and Education, and U.S. National Science Foundation. The authors are very appreciative of valuable guidance in the field by Juan-Carlos Braga and Julio Aguirre and also of important assistance with the fractal analyses by James
R. Lehane. The manuscript benefited significantly from valuable suggestions for improvement by Juan-Carlos Braga, Andreas Wetzel and José Antonio Gámez. The first author (AAE) is deeply indebted to the vital contributions of the second author (JMdeG), whose untimely death intervened before this project could be completed and before this manuscript was written. Without the keen observations, clever insights, sage interpretations and collegial friendship of Jordi Maria de Gibert, this paper never would have seen the light of day.

\section{REFERENCES}

Baucon, A. 2010. Da Vinci's Paleodictyon: The fractal beauty of traces. Acta Geologica Polonica, 60, 3-17.

Braga, J.C., Martín, J.M. \& Wood, J.L. 2001. Submarine lobes and feeder channels of redeposited, temperate carbonate and mixed siliciclastic-carbonate platform deposits (Vera Basin, Almería, southern Spain). Sedimentology, 48, 99116.

Braga, J.C., Martín, J.M., Riding, R., Aguirre, J., SánchezAlmazo, I.M. \& Dinares-Turell, J. 2006. Testing models for the Messinian salinity crisis: the Messinian record in Almería, SE Spain. Sedimentary Geology, 188-189, 131-154.

Ekdale, A.A. 1980. Graphoglyptid burrows in modern deepsea sediment. Science, 207, 304-306.

Ekdale, A.A. 1985. Palaeoecology of the marine endobenthos. Palaeogeography, Palaeoclimatology, Palaeoecology, 50, 63-81.

Feder, J. 1988. Fractals. Plenum Press, New York.

Gibert, J.M. de, Jeong, K. \& Martinell, J. 1999. Ethologic and ontogenic significance of the Pliocene trace fossil Sinusichnus sinuosus from the northwestern Mediterranean. Lethaia, 32, 31-40.

Honeycutt, C.E. \& Plotnick, R.E. 2005. Mathematical analysis of Paleodictyon: a graph theory approach. Lethaia, 38, 345-350.

Jiang, J. \& R. Plotnick, R.E. 1998. Fractal analysis of the coastlines of the United States. Mathematical Geology, $30,535-546$.

Kern, J.P. 1980. Origin of trace fossils in Polish Carpathian flysch. Lethaia, 13, 347-372.

Książkiewicz, M. 1970. Observations on the ichnofauna of the Polish Carpathians. In: Trace Fossils (eds Crimes, T.P. \& Harper, J.C.). Geological Journal, Special Issue, 3, 283-322.

Książkiewicz, M. 1977. Trace fossils in the flysch of the Polish Carpathians. Palaeontologia Polonica, 36, 1-208.

Lehane, J.R. \& Ekdale, A.A. 2012. Fractal analysis of graphoglyptid trace fossils. Palaios, 28, 23-32.

Mandelbrot, B.B. 1983. The Fractal Geometry of Nature. W.H. Freeman \& Company, New York.

Montenat, C. \& Seilacher, A. 1978. Les turbitites messiniennes a Helminthoides et Paleodictyon du basin 
de Vera (Cordilleres bétiques orientales): indications paléobathymétriques. Bulletin de la Société Géologique de France, 7, 319-322.

Plotnick, R. 1986. A fractal model for the distribution of stratigraphic hiatuses. Journal of Geology, 94, 885-890.

Rona, P.A., Seilacher, A., De Vargas, C., Gooday, A.J., Bernhard, J.M., Bowser, S., Vetriani, C., Wirsen, C.O., Mullineaux, L., Sherrell, R., Frederick Grassle, J., Low, S. \& Lutz, R.A. 2009. Paleodictyon nodosum: a living fossil on the deep-sea floor. Deep Sea Research, Part II: Topical Studies in Oceanography, 56, 1700-1712.

Seilacher, A. 1962. Paleontological studies on turbidite sedimentation and erosion. Journal of Geology, 70, 227-234.

Seilacher, A. 1964. Biogenic sedimentary structures. In: Approaches to Paleoecology (eds Imbrie, J. \& Newell, N.). John Wiley \& Sons, New York, 296-316.

Seilacher, A. 1967. Bathymetry of trace fossils. Marine Geology, 5, 413-428.

Seilacher, A. 1974. Flysch trace fossils: evolution of behavioural diversity in the deep-sea. Neues Jahrbuch für Geologie und Paläontologie, Monatshefte, 4, 233-245.

Seilacher, A. 1977. Pattern analysis of Paleodictyon and related trace fossils. In: Trace Fossils 2 (eds Crimes, T.P. \& Harper, J.C.). Geological Journal, Special Issue, 9, 289-334.
Seilacher, A. 2007. Trace Fossil Analysis. Springer-Verlag, New York.

Uchman, A. 2003. Trends in diversity, frequency and complexity of graphoglyptid trace fossils: evolutionary and palaeoenvironmental aspects. Palaeogeography, Palaeoclimatology, Palaeoecology, 192, 123-142.

Uchman, A. (ed.) 2008. Types of invertebrate trace fossils from Poland: an illustrated catalogue. Polish Geological Institute, Warszawa.

Valentine, J.W. 1969. Niche diversity and niche size patterns in marine fossils. Journal of Paleontology, 43, 905-195.

Wetzel, A. 1983. Biogenic structures in modern slope to deep-sea sediments in the Sulu Sea Basin (Philippines). Palaeogeography, Palaeoclimatology, Palaeoecology, 42, 285-304.

Wetzel, A. 2000. Giant Paleodictyon in Eocene flysch. Palaeogeography, Palaeoclimatology, Palaeoecology, 160, 171-178.

Wood, J. \& Poiré, D.G. 1998. Late Miocene ichnofauna in the Vera and Sorbas Basins, SE Spain: uses in the determination of onshore-offshore palaeoenvironment relationships on a temperate carbonate ramp. $15^{\text {th }}$ International Sedimentological Congress, Alicante, 824. 